\title{
Necropolitics and Necrocapitalism: The Impact of COVID-19 on Brazilian Creative Economy
}

\author{
Diego Santos Vieira de Jesus \\ ESPM-Rio: Creative Economy, Rio de Janeiro, Brazil \\ Email: dvieira@espm.br
}

How to cite this paper: de Jesus, D. S. V. (2020). Necropolitics and Necrocapitalism: The Impact of COVID-19 on Brazilian Creative Economy. Modern Economy, 11, 11211140.

https://doi.org/10.4236/me.2020.116082

Received: May 15, 2020

Accepted: June 14, 2020

Published: June 17, 2020

Copyright $\odot 2020$ by author(s) and Scientific Research Publishing Inc. This work is licensed under the Creative Commons Attribution International License (CC BY 4.0).

http://creativecommons.org/licenses/by/4.0/

(c) (i) Open Access

\begin{abstract}
The aim is to examine the impact of the COVID-19 pandemic on Brazilian creative economy, based on the concepts of necropolitics (Mbembe, 2003, 2018) and necrocapitalism (Tyner, 2019). The main argument indicates, also in line with Pelbart (2018) and Medeiros (2019), that the COVID-19 pandemic reinforced a political division between those who may or may not die, since some lives are considered disposable, especially those of creative professionals who have unstable and precarious conditions of work and are inserted in sectors seen as superfluous by the Brazilian state. Many of these people represent social minorities, who are the main targets of the economic and social death policies that have their legacy in violent practices linked to Brazilian colonization and slavery.
\end{abstract}

\section{Keywords}

Necropolitics, Necrocapitalism, COVID-19, Brazil, Creative Economy

\section{Introduction}

They agreed to kill us, but we agreed not to die.

(Conceição Evaristo, “Olhos d'Água", 2014)

The World Health Organization (WHO) describes COVID-19 as a flu-like infectious-respiratory disease. The infection rate is high, as there is no immunity due to previous illness or a protection by vaccine. A disease presents itself as dangerous to populations due to its potential for contamination or the risk of death. Because of the COVID-19 spread, there was a slowdown in the global economy, as well as fluctuations in the stock exchange or cancellation of public events. The new coronavirus allowed countries to close borders, prevent mobility in cities, and confine individuals to their homes (Diniz \& Carino, 2020). 
Fighting the pandemic required measures to restrict the functioning of manybusinesses and venues. Several were affected by social distancing measures, such as cinemas, hotels and restaurants. As the virus spreads, it becomes gradually possible to assess its social, economic and political consequences, as well as witness the mediatization of the pandemic, the closure of schools and universities, libraries and museums, the cancellation of sports competitions, the loss of income by workers and entrepreneurs and the negative impact of the pandemic on informal work (Maranhão, 2020).

In Brazil, COVID-19 had a negative impact in multiple sectors of the society during the administration of the president Jair Bolsonaro, elected from the coalition "Brazil Above Everything, God Above All", formed by the political parties PSL and PRTB. He won the first round of Brazil's 2018 presidential election, counting on more than $46 \%$ of valid votes. In the second round of the presidential election, Bolsonaro defeated the candidate Fernando Haddad, from the coalition "People Happy Again"-formed by the political parties PT, PC do B and PROS-, with more than $55 \%$ of the valid votes. The themes that dominated the political debates during the 2018 presidential election focused mainly on the fight against corruption and urban violence. Bolsonaro not only focused on the fight against corruption and crime, but also the revitalization of the "traditional values of the Brazilian family". As for culture, many Bolsonaro's speeches and tweets were directed against cultural and artistic expressions of black, indigenous and LGBT people, which motivated the reaction of countless members of the artistic and creative classes. His proposals for education did not stimulate the critical thinking and creativity of students and, in terms of innovation, the focus was predominantly on more traditional sectors of the economy (Jesus, 2019a, 2020).

When the COVID-19 pandemic started, Bolsonaro's public call for Brazil to get back to work and his efforts to undermine regional governments' shutdowns have appalled critics and sparked a political rebellion by the governors of many Brazilian states. In contrast, Health minister Luiz Henrique Mandetta advised Brazilians to follow local governments' advice on isolation. The governments of some of the most important creative cities in Brazil, such as São Paulo and Rio de Janeiro, followed Mandetta's recommendations. In April 2020, Bolsonaro fired Mandetta, after the two clashed over Bolsonaro's highly controversial response to the coronavirus pandemic. Mandetta's successor, Nelson Teich, said Brazil needed a full testing programme to better understand the new coronavirus and promised no "abrupt decision" on social distancing. He also made it clear Brazil would slowly start reopening (Phillips, 2020).

All over the world, the COVID-19 pandemic has affected the creative economy, which includes activities, goods and services based on individual and collective talent, such as advertising, the art markets, crafts, design, fashion, film, software, music, publishing, radio, TV and museums, for example (Bendassolli et al., 2009; Jesus, 2019a; Miguez, 2007). The specific impacts of the pandemic on the creative economy will be described in detail in the following sections, but it is 
important to say that many creative professionals lost their jobs due to the crisis because projects were either put on hold or cancelled, and clients rescinded their original plans and contracts with creative organisations. Most creative organisations were not hiring. With a huge majority of creative businesses on a hiring hiatus, an expressive number of creative professionals said they would not be able to live for more months without or with less work, despite the fact that many of them were already relying on savings and government financial support. Some unemployed creatives were trying to reinvent themselves and hoping the new skills would help them stand back on their feet when the pandemic was over. Freelancers particularly have been hit the hardest by the pandemic, losing a wealth of clients and having to rely on savings (Brewer, 2020). Before the pandemic, according to the Brazilian Institute of Geography and Statistics (IBGE, its acronym in Portuguese), the creative sectors employed approximately 1.9 million people (3.7\% of the employed), of whom $44 \%$ worked independently. The Industry Federation of the State of Rio de Janeiro (FIRJAN, its acronym in Portuguese) indicated that the creative sectors were responsible for $2.61 \%$ of the Brazilian GDP in 2017 (around US\$ 34.3 billions) (Mantica, 2020).

The aim of the article is to examine the impact of the COVID-19 pandemic on Brazilian creative economy, based on the concepts of necropolitics (Mbembe, 2003, 2018) and necrocapitalism (Tyner, 2019). The main argument indicates, also in line with Pelbart (2018) and Medeiros (2019), that the COVID-19 pandemic reinforced a political division between those who may or may not die, since some lives are considered disposable, especially those of creative professionals who have unstable and precarious conditions of work and are inserted in sectors seen as superfluous by the Brazilian state. Many of these people represent social minorities, who are the main targets of economic and social death policies that have their legacy in violent practices linked to Brazilian colonization and slavery.

\section{Theoretical Framework}

The Cameroonian postcolonial author Achille Mbembe $(2003,2018)$ defines necropolitics as the ultimate expression of sovereignty, which resides in the power and capacity to dictate who may live and who must die. The necropolitics predicates life on the death of the Other, and certain lives are more vulnerable than others. According to Mbembe (2003), necropolitics is more than a sovereign right to kill—which is a reference to Foucault's (1997) droit de glaive-, but also the right to expose other people-including the citizens of a state-to death, which includes the right to impose social and civil death, the right to enslave others and other forms of political violence. Foucault (1997) argues that biopower is the domain of life over which power has taken control, regarding the tactics that regulate which bodies must live and which can be disposable. According to Burton-Cartledge (2020), Foucault also argued that the state punished individuals with a set of technologies of discipline. The people who enter the state's institutions are disciplined by a specific regimen, in which the implied and overt vi- 
olence inflicted by state officers subject individuals. The fusion of power and knowledge provides standards, justifications, and crucially the pathways by which institutions address and expect people to behave. Although the disciplinary power has been supplanted by the surveillance of all by all, the population management and the inculcating/nudging appropriate regimes of governance remain the privilege of the capitalist state.

But one may question under what practical conditions the right to kill, to allow to live, or to expose to death is exercised and who the subject of this right is. An epidemic or pandemic can be an effusive moment for biopolitics: in the name of collective protection, bodies are controlled and real or imagined health boundaries are drawn. However, all biopolitics becomes necropolitics when inequality regimes determine which bodies are at risk (Diniz \& Carino, 2020). Necropolitics is more precisely about violence and risk, e.g., about how much of the population should be exposed to the possibility of premature death. The cutting of public services and the violence of poverty and economic and cultural destitution may be examples of how necropolitics works. The necropolitics-as well as biopolitics-is naturalized, and deaths are routinised as unavoidable consequences in the context of the dehumanization and the depoliticization of mortality (Burton-Cartledge, 2020).

Tyner (2019) argues that one's exposure to death is increasingly conditioned by his/her position in capitalism, and necrocapitalism not only lets die, but makes death productive as a vehicle for accumulation. According to Tyner (2019), it is necessary to take seriously the production of premature death as foundational to the conditions of precariousness. In the present day, the pervasive indifference to surplus or redundant bodies is matched only with a nascent preference toward the profitability of dying or dead bodies. One of the main forces of necrocapitalism is its structural violence in society. The "figures of dead labor" embody the material conditions and realities of death in our society and the stratified experiences of mortality which undergird this profitability. In this context, some people are more vulnerable to having their lives cut short and their deaths rendered profitable. They may also be held culpable for their own deaths. This has as much to do with the socioeconomics of inequality as it does with any biological predisposition toward premature death. In the light of this, massive casualties of poverty and malnutrition are subsequently banalized (Majumder, 2019).

In the context of necrocapitalism, neoliberalism assumes characteristics that go beyond mere economic policies and inserts itself in social relations. It produces precarious jobs, workers and, above all, ways of life guided by precariousness. The flexibilization of work, for example, was presented to society through a seductive discourse of greater autonomy in the management of work and time, but, given the weaker union organization, it led to precarious employment and working conditions, based on the needs of the companies. This flexibilization took various forms, such as functional, numerical and salary flexibility, consisting of the mobility and versatility of the workforce; the most arbitrary forms of 
hiring labor, in relation to deadlines, working hours and wages; the organization of semi-autonomous working groups; subcontracting; outsourcing; work by goals or projects, with a significant reduction in the companies' staff; and the increasingly intense use of intermittent work. Such workers carry out activities of a fragile, unstable and flexible contractual nature, with unsecured earnings, and have less rights than workers of an older proletariat and a conscience marked by constant deprivation and frustration and chronic uncertainty (Leite, 2019).

In the light of the development of necropolitics and necrocapitalism, there are different ways to die and kill, both physically and symbolically. The apprehension generated for specific groups is present, for example, in the question of whether political, economic and social rights will be lost. With the restriction of freedoms, the ways of being in the world are regulated, and subjectivities are symbolically killed. The right to kill-typical of necropolitics-inhibits what Butler (2018) calls the "right to appear", the claim made by some bodies that they are not disposable and carry lives that deserve to exist. According to this logic, social beings are recognized from produced and repeated norms. Before recognizing someone, conditions of recognition and precariousness come into play. It is not everyone who is recognized the same way. There are people whose lives are considered more precarious than others. As social bodies, people have to rely on what is outside, including conditions that may or may not allow their lives to be perceived as important if they are lost. Although all lives are vulnerable and precarious, not all lives are recognized as such. It is not by chance that so many social minorities suffer the consequences of the deterioration of social and economic support networks more than others and are differentially exposed to damage, violence and death, even though they may develop political skills to overcome this situation (Medeiros, 2019).

It is possible to argue that, for long-term investors, the COVID-19 pandemic might bring investment opportunities, and low-income laborers must die so that the lives deemed indispensable may live, occupying a purgatorial space of deathin-life or treated as if he/she no longer existed except as a mere tool of production. In this context, the governments do not govern over life, but they dictate death domestically and internationally. In the case of the COVID-19 pandemic, the U.S. sanctions have harmed the public health sector in Iran by slowing or entirely blocking the sale of medicine, respirators, and hygienic supplies needed to mitigate the pandemic. In this case, the United States has enacted the material destruction of human bodies and populations, central to necropolitics (Bobba, 2020).

Mbembe's and Tyner's arguments provide a way of thinking through the politics of the current moment. The COVID-19 pandemic is not only a medical or epidemiological crisis, but also a crisis of sovereignty. It reveals an emergent necropolitical landscape defined by actors that have power over life and those with power over death. The number of notifications, bans, and closures is useful in this regard. It is the indication of a return to the most basic techniques of territorial control and state power: the politics of border restriction, community 
management, business closure, and public dispersal. Citizens are further asked to self-discipline through social distancing. The unprecedented scale, speed, and global extent of these sovereign measures are necessary for sustaining life, as a reactionary version of necropolitics concerned with the management of life and death to reduce disease proliferation, mortality numbers, and the rate of infection more generally. However, the reactionary stance equally indicates the unevenness of state capacity. The COVID-19 pandemic has highlighted a longterm failure of some states to sustain public health and life, through their commitment to neoliberal agendas to end state welfare in favor of privatization. The necropower dynamics of COVID-19 and other epidemics and pandemics are of slow violence: after decades of reduced infrastructure for medical care in many countries, national governments cannot guarantee or even manage life, except through the crudest forms of non-medical state control and cold violence against non-citizens. The definition of who gets to live and who gets to die is dependent on the goodwill, ability, and expertise of medical workers and others directly engaged with the situation. The power to dictate who may live has been outsourced and increasingly privatized, available only to those who can afford it (Lee, 2020).

In the light of the fact that the necropolitical landscape has largely remained invisible, the global capitalism has also concealed this political dispensation, highlighting the sharp decline of the world economy and fears of capitalist recession, which have garnered equal attention to the disease itself, with Global North solutions to the pandemic being envisioned in monetary terms in addition to the sovereign measures. The framing of the COVID-19 pandemic as an economic crisis is not only revealing of what priorities of sovereignty are at work, but it also indicates the limited tools of the neoliberal state power in relation to matters of crisis and social disorder that do not relate directly to fiscal policy. The immediate measures sustain the economic livelihoods of those hardest hit should not distract from or appease the pursuit of long-term solutions to economic injustice. The emergent necrocapitalism in times of the COVID-19 pandemics discloses the corrosive effects of neoliberal policies over economic life through the erosion of social security programs, unemployment welfare, or public education. The necropolitics and necrocapitalism reorganized the sovereign state power away from securing life and sustaining well-being to being primarily concerned with the arbitration of death (Lee, 2020).

Pelbart (2018) deals with the Brazilian particularity and points out that the necropolitics in the country is related to the colonial era, in which the arrival of the European colonizers was linked to the invasion of indigenous lands and the capture of the African population for slave labor. Deprived of their humanity and the control of their own bodies by Europeans, Africans were transported on slave ships and were promptly flogged when they arrived at their masters' farms, so that torture techniques cruelly imposed hierarchy among white and black people. In the Brazilian territory, Africans and indigenous peoples were dehumanized, physically and symbolically assaulted and exterminated. Such people 
were prevented from having the psychological strength to create a symbolic world, since their physique, constantly challenged by hard work and torture, was taken to exhaustion. They were also deprived of forming groups and affective ties, seen as a risk because of possible rebellions. In this sense, hatred and violence against social minorities began in colonial Brazil, in which bodies were controlled through techniques such as genocide and compulsory sterilization. According to Medeiros (2019), Pelbart (2018) argues that, although the necropolitics that Mbembe (2003) deals with is racialized, there are other dimensions that can cross it, such as gender, sexual orientation, origin and income. In contemporary Brazil, many creative workers represent social minorities, and the precariousness of their condition was reinforced by the COVID-19 pandemic, as the following sections will show.

\section{Methods}

The exploratory research used the qualitative method of case study, which, according to Bennett (2004), refers to the internal analysis of a specific situationthe impact of COVID-19 on Brazilian creative economy-and deals with well defined aspects of the historical event selected for investigation. Regarding the collection of evidence for the case study and the defined aspects of the event, a document and a bibliographic research were initially carried out to detect the main proposals of Bolsonaro's 2018 presidential campaign and the main political decisions of his administration, specially their effects on culture and creative economy. In a second moment, the main impacts of the COVID-19 pandemic on the cultural and creative sectors of Brazilian economy were indicated. The aim was to identify the main challenges for the creative sectors before and during the pandemic and how the Brazilian administration dealt with these issues. Finally, the results were interpreted in the light of the theoretical discussion on necropolitics and necrocapitalism to deal with the particularity of the Brazilian culture and creative sectors and professionals, and some recommendations to overcome the challenges brought by the COVID-19 pandemic are given.

\section{Results}

\subsection{Necropolitics and Jair Bolsonaro's Administration}

Bolsonaro has had controversial and aggressive stances in his political trajectory, which hurt social equality, attack democracy and disrespect social minorities that seek to gain identity recognition, transform asymmetrical relations and claim their presence in power decisions. Bolsonaro's rise and election represented, for these groups, a danger to national democracy. Among the political persuasion strategies used by Bolsonaro, it is possible to highlight the use of the population's lack of belief and hope to convince the masses, the unification of different opponents in the figure of a common enemy responsible for social problems-in this case, PT's administrations-and the inflammation of people's emotions, with the encouragement of symbolic and physical violence against those who disagree 
with his political group's positions and the evocation of the dictatorship as a solution to Brazil's problems (Medeiros, 2019).

Even before taking office, Bolsonaro said some key members for his cabinet would be the Lava Jato Operation's judge Sergio Moro as the head of the Justice Ministry. The Lava Jato Operation is a set of investigations underway by Brazilian Federal Police, which began in March 2014. The operation investigates crimes of active and passive corruption, fraudulent management, criminal organization and obstruction of justice, among others (Jesus, 2019a). Bolsonaro indicated the University of Chicago-trained Paulo Guedes as the leader of the newly-created Economy Ministry and the evangelical pastor Damares Alves as the head of the newly-created Women, Family and Human Rights Ministry. Bolsonaro indicated the largest number of active and former members of the military for government functions since Brazil's return to democracy. Bolsonaro's government members established important changes in the first months of his administration. Guedes promised to cut taxes, reduce public spending and reform the pension system. Moro presented a package of proposals named the Anti-Crime Law to fight corruption, criminal organizations and violent crimes and said that organized crime fed more corruption. LGBT concerns were removed from the purview of the Women, Family and Human Rights Ministry, headed by Alves, which brought fears to LGBT people that they would have less protections from the government, considering Bolsonaro's homophobic comments throughout the campaign and Alves's view that diversity politics threatens "the Brazilian family". Foreign Minister Ernesto Araújo has praised the strengthening of the cooperation with the United States and anti-globalist views, as well as the criticism toward leftist governments. He even said that one of Brazil's greatest problems was the "comunavirus" in reference to communism and leftist ideas. The second Education Minister during Bolsonaro's administration, Abraham Weintraub, threatened to limit the resources for public universities, necessary to invest in innovation and development (Gonzalez \& Leme, 2019; Jesus, 2020).

Nevertheless, many changes proposed by Bolsonaro's government faced resistance by many sectors of Brazilian population, as well as difficulty in their implementation. Some changes-including the pension reform-depended on the Congress' approval. Other issues such as the intervention from the president's sons in the government decisions, Bolsonaro's controversial tweets about the negotiation with the Legislative chambers and the cabinet's splintering into military, evangelicals, moderates, and anti-globalists have brought turbulence. Some decisions such as the easing of restrictions on gun possession in Brazil were implemented and faced the resistance of many groups such as human rights NGOs. The fight against corruption seemed more difficult, given the investigations linking one of the president's sons, Rio de Janeiro's Congressman Flavio Bolsonaro, to suspicious cash transactions, as well as investigations over Bolsonaro's political party in the 2018 elections-PSL-registering fake candidates to receive public campaign funds (Gonzalez \& Leme, 2019; Jesus, 2020). In April 2020, Moro 
decided to leave the government after Bolsonaro fired Federal Police GeneralDirector MaurícioValeixo, named by the former justice minister. Moro resigned in the light of the president's attempt to interfere in the Federal Police and halt investigations into presidential allies.

According to Dias \& Gonçalves (2020), the government of Brazilian president Jair Bolsonaro institutionalized the necropolitics in a country with a fragile and young democracy, which has not been consolidated for millions of people, particularly Afro-Brazilians and other marginalized groups. A part of the government's supporters seems to believe in a democracy only on the paper and a dictatorship on the streets, and others openly defend the return of the military to power. During the 2018 presidential elections, cases of political violence and death spread across Brazil. Many conservative groups responded violently to previous administrations that solidified public policies for the poor and marginalized groups, removed millions from below the poverty line and leveraged their social insertion into the middle class. These social advances triggered a backlash of hate, and the largest low-income black population witnessed its genocide levels surpass acceptable numbers for a democracy. With the polarization in Brazil, the political action centralized on the large-scale production of death at the hands of the state, particularly against the women, black and LGBT people. The many misogynist, racist, homophobic and transphobic declarations made by Bolsonaro proved that, more than not respecting these people, he views them as enemies.

In the newly elected Congress, there is an intense political party fragmentation and a rightward swing on social issues. Most newly elected congressmen come from traditional political families or are evangelical leaders or hardline police officers. The far-right members of the Congress repeated Bolsonaro's most barbaric and violent ideas, which shows that class struggle in Brazil is alive. His election comes on the track of elections in other countries in which the extreme right is gaining strength. This brings a counter-flux against human rights. Bolsonaro promised to end race-based quotas in universities and civil service exams, as well as the public-school system's gender policy. The key issues for his administration are related to security, but there have been no clear promises beyond relaxing gun ownership legislation. The "Bolsonaro myth" was consolidated through hatred against leftist leaders and his portrayal as a fighter against corruption, although many corruption allegations were made against members of his family. In the economic area, the market has bought into the idea that Bolsonaro is more neoliberal and willing to privatize the state companies to reduce the public debt (Dias \& Gonçalves, 2020).

When the COVID-19 pandemic started, Bolsonaro has repeatedly downplayed the severity of the outbreak and dismissed the virus as a "little flu", shrugging off social distancing recommendations from the WHO and sharing videos calling for an end to the country's lockdown. Mandetta criticized Bolsonaro for refusing to abide by the Health Ministry's social distancing guidelines, while his successor Teich said there was a complete alignment among him, the 
president and the ministry. The move came as hospitals and clinics teeter on the brink of collapse. Emergency rooms were running at capacity, with almost all intensive care beds and ventilators occupied in some Brazilian states. Gravediggers in the country's largest cemeteries worked overtime to bury the dead (Lopes, 2020).

The scenario surrounding the new coronavirus pandemic unfolded very quickly, and thecatastrophic consequences were gradually seen. While the virus spread in Brazilian territory, the Provisional Measure 936/2020- published by the Federal Government in early April 2020-did not bring security and protection to the needy population at the time of crisis. On the contrary, it triggered the acceleration of the precarious working conditions of a large part of the Brazilian population (Maranhão, 2020). The precariousness of work in Brazil can be identified in the vulnerability of forms of insertion in the work market and social inequality, which refers to precarious contracts, with no social guarantees, as well as unemployment. Such precariousness is also evident in the intensification of work and outsourcing, which are the forms of work organization through the management of fear, moral harassment and the imposition of unattainable production goals on workers. The precariousness can also be seen in job insecurity, the result of organizational and management models based on the lack of training of workers and the omission of information on risk, dangerousness and protection measures, with a view to increasing productivity. Some of the forms that such precariousness takes-which became more intense with the COVID-19 pandemic - were the loss of individual and collective identity, increasing the fear of job loss and isolating workers; the weakening of the labour organization, represented by the difficulty of union organization, which lost the ability of the unions to mobilize workers; and the condemnation and dismissal of labor law, which, in the contemporary Brazilian context, has its strongest representation in the Labor Reform (Druck, 2011). Coping with the COVID-19 pandemic further exposed workers' historical demands regarding working conditions, personal protective equipment, workload, pay and the invisibility of some professional categories (Maranhão, 2020).

In culture and creative economy issues, Bolsonaro has been criticized for pushing a conservative Christian cultural agenda while cutting funding to arts and cinema projects. His allies have lashed out at what they call "cultural Marxism" and condemned everything from climate change to feminism (Cowie, 2020). The gradual weakening of specific bodies dedicated to culture and creative economy since 2015 has reached the top in the first year of Bolsonaro's administration. Strategic decisions related to such economy were emptied and abandoned with the end of the Ministry of Culture by Bolsonaro's administration, and cultural issues were relegated to the background or diluted into other federal government bodies, such as the Ministry of Citizenship and, more recently, the Ministry of Tourism, which lack the specific knowledge of the particularities of cultural and creative demands. Bolsonaro first abolished the Ministry of Culture, which became a secretariat under the new Ministry of Citizenship. He limited funding for 
cultural and artistic sectors and modified the National Council for Cultural Policy, which is fundamental in the collective construction of cultural policies. The special secretary of Culture, Henrique Pires, left office in August 2019, after the Ministry of Citizenship suspended a public notice dedicated to LGBT series. Pires saw the decision as a kind of censorship. The decision to suspend the public notice was taken amid several criticisms by Bolsonaro regarding the allocation of public resources to films and series with themes that displeased the president, such as LGBT issues. In November 2019, Bolsonaro dismissed the special secretary of Culture, Ricardo Braga, two months after he took office, and said that, if he could not impose "filters" on the choices of the National Film Agency (Ancine, its acronym in Portuguese), he would eliminate the agency (Jesus, 2019b).

In the month before Braga's dismissal, the former mayor of the city of Santa Maria Cezar Schirmer became the new Secretary of Creative Economy, linked to the Special Secretariat of Culture of the Ministry of Citizenship. Among his attributions, the articulation of financing lines for cultural enterprises, the promotion of Brazilian cultural goods and services and the implementation of access to reading policies could be mentioned. Nevertheless, Schirmer did not seem to have experience in matters related to creative economy. In November 2019, Bolsonaro transferred the Special Secretariat of Culture from the Ministry of Citizenship to the Ministry of Tourism. In the light of the change, the Ministry of Tourism became responsible for the national culture policy, the regulation of authors' rights, the protection of historical, artistic and cultural heritage, the support to the Ministry of Agriculture for the preservation of the cultural identity of quilombola communities and the development of cultural accessibility and museum sector policies. The Ministry of Tourism tried to highlight the joint projects with the Ministry of Citizenship and indicated that the transferring of the Special Secretariat of Culture from the Ministry of Citizenship could strengthen the actions of each area. The government also indicated the playwright Roberto Alvim to head the Special Secretariat of Culture. Bolsonaro said that the new secretary had "carte blanche" to form his team with "competent people". Before taking office, Alvim called Brazilian Oscar-nominated actress Fernanda Montenegro a "liar" and said she was "sordid" in a Facebook post, which provoked the reaction of the artistic class in the defense of the actress (Jesus, 2019b).

In January 2020, Alvim was fired after he paraphrased the Nazi propaganda minister Joseph Goebbels in an online video to promote a national arts prize (Cowie, 2020). In the same month, the actress Regina Duarte accepted the offer to be the Special Secretary of Culture and replace Alvim. However, in May 2020, Duarte abruptly ended an interview with a TV station when confronted with criticisms by the actress Maitê Proença on how she was helping the artistic class during the COVID-19 pandemic. Besides downplaying the deaths during Brazilian military dictatorship, Duarte also said there was a certain "morbidity" due to the COVID-19 pandemic. After being silent regarding the death of several artists since taking office in March 2020 (many of them caused by COVID-19), Duarte 
said that she did not want to work on "obituaries" in the ministry (Fernandes, 2020).

\subsection{Creative Economy and the COVID-19 Pandemic in Brazil}

The COVID-19 pandemic has had negative impacts on global tourism, financial markets, live entertainment, personal services, restaurants and food value chains as well their supply businesses all over the world. Some people-mainly the least well paid, the self-employed and the ones working in informal environments in the gig economy or in part-time work with zero-hours contracts-were the most affected. The pandemic made explicit the inequalities of globalization, its democratic shortfalls and the disproportionate impact on vulnerable people. Regarding creative economy, the relations among the sector characteristics, the health sanctions and the consumer behavior showed that some sectors might be more vulnerable to the impact of the COVID-19 contractions than others. Some creative sectors such as live music, theater, dance, live entertainment, event sector supplies, museums, galleries, and tangible cultural heritage were highly exposed to the pandemic and might experience sustained revenue losses along 2020, which could push them to bankruptcies or credit defaults. These sectors needed to pivot through innovation or diversification to survive. Other sectors such as fashion, visual arts, restaurants, traditional cuisine, street food and crafts might also sustain revenue losses, have a chance to engage survival strategies and prepare for a relatively slow recovery. They could re-engineer their supply chains, as well as create new products and services through innovation in response to consumer behavior and develop innovation in supplies, such as digital and virtual individual/group learning methods, purchases and sales, customer logs, logistics and delivery. Some sectors with low touch production and distribution characteristics seemed to have more limited exposure to the impact of COVID-19, such as music recording and radio, film, TV, and digital content, home gaming, online e-sports and digital publishing. The consumption of the products of these sectors has remained the same and may even have increased, but it is not possible to ignore that there are bottlenecks in production timelines and even product movement brought about by the social distancing measures. They might experience revenue growth as a result of a demand surge and require business support, customer service and growth capital to push for market share and increase safe production capacity and digital distribution (Khasiani et al., 2020).

In the Brazilian political dimension, the creative economy has become a central concept, seen by many government members as the engine of income and employment generation and social inclusion in the now-defunct Ministry of Culture since the 2000s. The concept assumed strategic roles, given the potential loss of importance of commodity exports, as well as the growing role of commercialization of high value-added goods and services. However, since the mid2010s, the discussions about culture and creative economy have seemed to have no clear direction in the national political debates in the light of the growing political and economic crisis in the country, but the dismantling of the creative 
economy debate and the role of culture in the Brazilian strategy of development became clearer especially after the beginning of Jair Bolsonaro's administration in 2019 (Jesus, 2019b).

The creative economy was one the most affected areas by crisis caused by the new coronavirus in Brazil. Since the beginning of March 2020, the dynamics of the creative economy have undergone the shock of the determinations necessary to control the COVID-19 pandemic, such as the closure of public spaces, the cancellation of shows and the suspension of the production of new movies and records, for example. In the case of music and concerts, the crisis affected not only the artists, but also technicians, organizers, show houses' owners and employees, communication vehicles' professionals, technical and logistic suppliers. As many of these professionals are freelancers or work in small companies, they are in a situation of extreme difficulty due to the cancellation or suspension of concerts and shows. Companies in the music industry-particularly the smaller ones-may go bankrupt. Freelancers, who depend om week-long wages to pay the costs of the following week, face difficulties to give better life conditions to their families. Several musicians are promoting online concerts and performances, some with economic results generated by the views in streaming platforms and the sponsorship of important brands. Some brands even started to promote online events with various artists. However, less famous artists face problems to monetize their online performances. In the case of large shows that were postponed, many organizers are asking ticket owners not to request a refund, which could reduce the impact on the cash flow. Probably, when social distancing measures are abolished, many people will not want to participate in large events or attend crowded clubs. The government has not yet defined a specific line of support for the cultural sector in general, but private cultural institutes are launching initiatives to stimulate and reward the production of musical compositions and studies on Brazilian music (Mantica, 2020).

The culture sector suffered from the impacts of the closing of concert halls. Many famous Brazilian artists cancelled or postponed concerts-such as Ney Matogrosso, Djavan, Marília Mendonça and Racionais—as well as album releases, such as Caetano Veloso's and Wesley Safadão's new albums. Music professionals who work in more informal conditions-such as musicians of samba wheelssuffer even more from the indefinite stoppage. Theater directors and actors cannot rehearse, and the promises of good billing options for the theater scene have turned into debts. Many theater and dance companies are being forced to negotiate the rent of spaces where rehearsals and shows take place, in addition to places where they store elements of sets and costumes. The pandemic has further aggravated a crisis scenario, in which a large part of the theatrical shows on display throughout the country had already suffered from the lack of sponsorship. In general, the expenses were covered by the money at the box office, but, with the prohibition on holding public events, this amount of money is not available. Leaders in the theater sector indicate the need to call on the government to mitigate the damage from paralysis, such as the publication of notices that allow 
creative theater professionals to work from home with remuneration. Although some Brazilian states such as Rio de Janeiro have banned power, water and gas cuts in the case of non-payment of bills by theaters, museums and concert halls, this is not enough for many creative professionals. In some museums, processes and strategies are being revised with the help of technology, which has become a vital tool for moving forward. The most immediate response from the creative class, as in other countries affected by the COVID-19 pandemic, came through the more intense and commercial use of the virtual world, with the online performance of theater plays on social networks, for example (Araújo, 2020).

The technicians in the TV and cinema sectors suffer from the economic instability because they typically work in very precarious conditions and with no contractual safeguards. This situation makes them more exposed to the negative economic effects of the pandemic. The production phase of TV and cinema sectors was stopped, which will lead to a decrease in new releases next year. Creative productions that have already been produced and are in the post-production phase probably can still be launched in 2020 or 2021. All soap operas' productions have been discontinued, and some production companies have already dismissed freelancer collaborators since the beginning of the COVID-19 pandemic. In TV, variety and information programs which included the presence of the public have been cancelled, reformulated, replaced by reruns or suspended to give more coverage to the COVID-19 news. With the success of the live performances of artists on social networks, commercial TV companies are trying to exhibit these performances to stem the loss of audience and consequent advertising revenue. The advertising sector faces a severe crisis because campaigns were cancelled or suspended, and the production of new commercials have been interrupted. The situation has led to the resignation of many freelancers and technicians who work for advertising agencies or production companies. Some associations in the sector have asked the government for support measures to preserve jobs and the survival of many communication agencies (Mantica, 2020). In the photography sector, creative professionals have been unable to make official bookings for photography jobs as most clients are not willing to come to studios, leading to drastic reduction in sales. The advertising photography jobs are at a standstill as well, as licenses to shoot are currently not being given out by the authorities (Khasiani et al., 2020).

In the movies' sector, some producers are still waiting for the reopening of the movie theaters or scheduling the launch of the movies on the streaming platforms, with heavy economic consequences. With the cinemas closed because of the risk of people's agglomeration, all the movie exhibitions in movie theaters were suspended. Some cinemas are trying to offer the viewing of author films online to generate alternative revenues and pay at least part of their fixed costs. With the significant increase in the permanence of people in their own homes, people seek refuge or distraction in streaming platforms, such as Netflix. Some Brazilian companies that offer streaming content have seen the demand for access increase and other initiatives are being created to take advantage of the market 
opportunity brought by the pandemic (Mantica, 2020).

As Khasiani et al. (2020) indicated in the case of Kenya, Brazilian creative professionals also started to develop strategies and innovations in their immediate term responses to the COVID-19 crisis. Some creative sectors have brought new models through experimentation and innovation to increase their resilience and continue their activities during the pandemic. These models include the reduction of overall expenses, the search for new business, the creation of new products and funds, the offer of digital solutions to others whose businesses are suffering because of the lockdown and discounted rates to help others get through the difficult time and the realization of online workshops. However, the proposed strategies and innovations do not have the same effects for all creative businesses and professionals, specially the small ones.

\section{Analysis and Discussion}

Bolsonaro's rise to the position of "the solution for all national problems" during the elections stemmed from a lack of political confidence in parties and coalitions that had been in the executive branch for years, the popular anger against corruption, the economic crisis and the high crime rates. Bolsonaro also incorporated a type of conservatism found in various sectors of the Brazilian population, which aims at maintaining privileges of gender, sexuality, race and class to those already privileged and the revocation of rights of social minorities. The spread of hate practices-based in a politics of fear-left a warning to anyone who disregarded the pro-Bolsonaro ideals because of their sexual orientation, race, gender identity or political opinion (Medeiros, 2019).

During Bolsonaro's administration, strategic decisions related to the greater role of culture in the promotion of income and jobs, the appreciation of heritage and memory and the revitalization of urban areas were abandoned or neglected. When the Special Secretariat of Culture was transferred from the Ministry of Citizenship to the Ministry of Tourism, the government seemed to conceive that culture was important for national development only if it could bring more tourists to Brazil (Jesus, 2019b). In Brazil, during Bolsonaro's administration, there were cuts in health and education budgets and precarious work relationships. Budget cuts affected research and the Unified Health System (SUS, its acronym in Portuguese). When the population is not killed by police violence, people are killed with no access to health care nor possibilities for social advancement. The necropolitics in Brazil has been accompanied by the denial of science and human rights, from gender relations to the respect to indigenous, black and quilombola peoples. A process of depreciation of the arts, philosophy, history, sciences in general-and social sciences in particular-is visible in favor of a proposal based on religious fanaticism, conservatism and the militarization of teaching (Granada, 2020).

Necropolitics is related to contemporary forms that subjugate life to the power of death and performs a reconfiguration in the relations of resistance, sacrifice and terror in contemporary societies (Mbembe, 2003, 2018). Critical authors of 
neoliberalism recognize the system as incompatible with the fight against inequality and maintain that neoliberal policies would be policies of death, either by the action of the police force or by letting those who are not "useful" to the system perish and die in the name of the good functioning of the economy (Tyler, 2019), as in the case of creative professionals in the context of the COVID-19 pandemic. Both the actions and the omissions of the federal government, especially those of the president, can be understood as parts of a broader perverse policy of letting the most vulnerable, the poor, the elderly and all those who are not considered useful or productive die, relegated to the condition of "living dead" (Granada, 2020). From a biopolitical point of view, the social distancing has as its main consequences the advertised desire to clamp down on the communication of disease and the management of populations at a moment of national crisis. The atomization of people in their homes creates protection against outbreaks of mass hysteria and allows for the forcible removal of the infected ones. Necropoliticstakes place when the fate of the vulnerable is considered, particularly the sufferers on the basis of age, underlying health conditions, record of economic activity or some other indices of social desirability. The population management strategy exposes vulnerable people even more to the risk of death thanks not only to arbitrary assessment criteria in hospitals, but also to the "forgetting" of workers and others who simply cannot find jobs or develop their work during the pandemic (Burton-Cartledge, 2020). This is the case of most creative professionals in Brazil, who subsist on social security and seek work in non-favourable conditions in the context of the COVID-19 pandemic.

The situation is aggravated because many creative professionals lack the awareness about the existence of unions to defend their rights. Many unions fail to attract membership due to the lack of resources for effective membership, and the fragmentation and disorganization of these institutions is not rare. This has led to rivalry and duplication of roles by different unions. Other creative professionals avoid or evade organization memberships due to the wariness of additional responsibilities and labor for the sector which may be voluntary or undervalued, or take time away from their personal practices. Many professionals prefer the lightness of informal business practice at the start of their enterprise journey, and so do not register legally or pay taxes because of the phase at which their business may be (Khasiani et al., 2020).

The intensification of precarious work was fueled by productive restructuring, relocation, deregulation, financialization and outsourcing and questions the status and wage relationship previously conceived and structured by the Fordist/Keynesian mode of regulation. The precarious economic situation was already present in Brazil and other countries in the deconstruction of collective contracts, the institutionalization of instability through a disruption of labor law and the decline in the strength of organized workers and their unions. The growth of work in the service sector was characterized by low wages and intense turnover, and the increased use of applications on digital platforms that mediate work by providing the meeting between supply and demand of work/service 
exempts app companies from their responsibilities towards workers, seen as "collaborators" (Leite, 2019). This precariousness intensified under the Bolsonaro's government and seemed to reach even higher levels in the context of the COVID-19 pandemic.

\section{Conclusion}

The desire for social minorities-many members of these groups are connected to creative sectors - to die or the will to kill them, whether symbolically or not, is manifested in the legacy which involves indigenous genocide and the enslavement of black people. Social minorities in contemporary Brazil move from the space of exclusion to that of extermination. Because they are not considered "good citizens", such people are seen as delays to the functioning of the nation. Therefore, their lives matter less by those in power today in Brazil. Bolsonaro and a significant part of his electorate reproduce the violence that affects bodies seen as dissonant (Medeiros, 2019).

In this context, the vulnerability of creative economy achieved its highest point during Bolsonaro's administration, which is visible in more unsatisfactory funding policies than in the past, non-favorable legal structures to a productive relationship between authorities and creative sectors, and the perpetuation of cultural marketing to the detriment of robust public policies of appreciation of creative sectors and professionals (Jesus, 2019b). According to Ribeiro (2016), the transversality of public policies for creative economy is compromised, and the Brazilian state loses its capacity for concerted action and integration among social and political actors.

After the COVID-19 pandemic, it is possible that creative sectors continue to experience intermittent limitations on movement and travel, bans on gatherings and the closure or near closure of borders. There may also be limited access to capital for creative businesses and grants for culture and the arts, as Brazilian and other governments are tending to numerous emergencies with limited revenues. Another tendency may be the increase in the use of contactless technology and digital platforms for generation, production, sharing and dissemination of creative goods and services, as well as the disruptions of supply chains affecting goods (textiles, dyes, paint, equipment), as well as exhibitions, festivals and conferences facing the difficulty to have buyers, benefactors and suppliers. In some areas, there may be a change in the consumers' behavior with more time spent at home, with increased digital interactions and consumption, health consciousness and general anxiety (Khasiani et al., 2020).

The pandemic left some important lessons for the creative sectors regarding the need for creative professionals' representation organizations to advocate on behalf of their interests and fight against precarious labor conditions. These professionals also need to look for alternative grant mechanisms and supply chains for critical goods and services to reduce their vulnerability. The widespread use of digital tools to maintain essential social interactions despite physical restrictions may bring opportunities for new creative businesses through 
e-commerce and the creation of online content that activates local and regional value chains (Khasiani et al., 2020).

It is important to indicate the limitations of this article. The exploratory research is usually conducted to have a better understanding of the existing problem, but usually it does not lead to conclusive results. The focus of the article is mostly theoretical and, to better discuss the impacts of COVID-19 in Brazilian creative economy, the use of quantitative data to support the view will be necessary in the future, especially when the pandemic is over. Although case studies allow the use of contingent generalizations to model complex relationships, they have potential limitations, such as the difficulty of perfectly controlling comparisons among cases, in addition to the inherent ones, such as relative inability to make judgments about the frequency or representativeness of particular cases and their weak ability to estimate the causal weight of the causal phenomena (Bennett, 2004).

\section{Conflicts of Interest}

The author declares no conflicts of interest regarding the publication of this paper.

\section{References}

Araújo, B. (2020). Cultura: Empresários apontam soluções para reeguer o setor póspandemia. Veja Rio. https://vejario.abril.com.br/coronavirus/quarentena-cultura-brasil

Bendassolli, P. F., Wood Jr., T., Kirschbaum, C., \& Cunha, M. P. (2009). Indústriascriativas: Definição, limites e possibilidades. $R A E, 49,10-18$. https://doi.org/10.1590/S0034-75902009000100003

Bennett, A. (2004). Case Study Methods: Design, Use, and Comparative Advantages. In D. F. Sprinz, \& Y. Wolinsky-Nahmias (Eds.), Models, Numbers, and Cases: Methods for Studying International Relations (pp. 19-55). Ann Arbor: The University of Michigan Press.

Bobba, A. (2020). The Necropolitics of the Coronavirus: Who May Live, Who Must Die. Wear Your Voice. https://wearyourvoicemag.com/necropolitics-coronavirus-government

Brewer, J. (2020). Half of Currently Unemployed Creatives Lost Their Job Due to Coronavirus, Says Survey. It's Nice That.

https://www.itsnicethat.com/news/creativepool-coronavirus-survey-creative-industry$\underline{110520}$

Burton-Cartledge, P. (2020). The Necropolitics of Coronavirus. All That Is Solid. http://averypublicsociologist.blogspot.com/2020/03/the-necropolitics-of-coronavirus.h $\underline{\mathrm{tml}} \mathrm{m}=1$

Butler, J. (2018). Corpos em aliança e a política das ruas. Rio de Janeiro: Civilização Brasileira.

Cowie, S. (2020). Brazil Culture Secretary Fired after Echoing Words of Nazi Goebbels. The Guardian.

https://www.theguardian.com/world/2020/jan/17/brazil-culture-minister-goebbels-rob erto-alvim-nazi

Dias, G. S., \& Gonçalves, J. (2020). Bolsonaro and the Institutionalization of Necropolit- 
ics. Brazil Wire.

https://www.brasilwire.com/bolsonaro-and-the-institutionalization-of-necropolitics

Diniz, D., \& Carino, G. (2020). A necropolítica das epidemias. El País. https://brasil.elpais.com/opiniao/2020-03-09/a-necropolitica-das-epidemias.html

Druck, G. (2011). Trabalho, precarização e resistências: Novos e velhos desafios? Caderno CRH, 24, 37-57. https://doi.org/10.1590/S0103-49792011000400004

Fernandes, T. (2020). Brazil's Secretary of Culture Abruptly Ends Live TV Interview When Criticized. Folha de S. Paulo. https://www1.folha.uol.com.br/internacional/en/brazil/2020/05/brazils-secretary-of-cul ture-abruptly-ends-live-tv-interview-when-criticized.shtml

Foucault, M. (1997). Ilfautdéfendre la société: Coursau Collège de France, 1975-1976. Paris: Seuil.

Gonzalez, E., \& Leme, L. (2019). Tracking the First 100 Days of Brazilian President Jair Bolsonaro. $A S / C O A$.

https://www.as-coa.org/articles/tracking-first-100-days-brazilian-president-jair-bolson $\underline{\operatorname{aro}}$

Granada, D. (2020). A gestão da pandemia do Coronavírus (Covid 19) no Brasil e a necropolítica: Um ensaio sobre uma tragédia anunciada. Boletim n. 15 Ciências sociais e coronavírus.

Jesus, D. S. V. (2019a). When Creativity Dies: Creative Economy in Brazil's 2018 Presidential Election. International Journal of Development Research, 9, 26335-26339.

Jesus, D. S. V. (2019b). The Risk of Irreversible Damages: Brazilian Creative Economy in the First Year of Jair Bolsonaro's Administration. International Journal of Development Research, 9, 32872-32875.

Jesus, D. S. V. (2020). Is "The Myth" Still Alive? Media and the Construction of Political Scandals during the First Months of Jair Bolsonaro's Administration. Compolis, 1, 71-83.

Khasiani, A., Ngumi, N., Karanja, G. A., Njuguna, W., Kabugi, N., Dolat, S., Muia, O., Kang'ethe, J., \& Gachara, G. (2020). COVID-19 Resilience: Creative Industry Options and Strategies. Nairobi: HEVA Fund LLP.

Lee, C. J. (2020). The Necropolitics of COVID-19. Africa Is a Country. https://africasacountry.com/2020/04/the-necropolitics-of-covid-19

Leite, K. C. (2019). Trabalho precário: Precariado, vidas precárias e processos de resistências. Política \& Trabalho, 51, 108-125.

Lopes, M. (2020). Brazil's Bolsonaro Fires Health Minister Mandetta after Differences over Coronavirus Response. The Washington Post.

https://www.washingtonpost.com/world/the_americas/coronavirus-brazil-bolsonaro-lu iz-henrique-mandetta-health-minister/2020/04/16/c143a8b0-7fe0-11ea-84c2-0792d859 1911_story.html

Majumder, D. (2019). Book Review: Dead Labor: Towards a Political Economy of Premature Death by James Tyner. LSE.

https://blogs.lse.ac.uk/lsereviewofbooks/2019/10/23/book-review-dead-labor-towards-a -political-economy-of-premature-death-by-james-tyner

Mantica, R. (2020). The Impact of the Coronavirus Crisis on the Creative Industry in Brazil. Update Brazil.

https://updatebrazil.com/2020/04/28/the-impact-of-the-coronavirus-crisis-on-the-crea tive-industry-in-brazil

Maranhão, R. A. (2020). Os Cientistas Sociais No Combate Ao Coronavírus E Contra A 
Necropolítica: Primeiras Batalhas. BOCA, 2, 1-14.

Mbembe, A. (2003). Necropolitics. Public Culture, 15, 11-40. https://doi.org/10.1215/08992363-15-1-11

Mbembe, A. (2018). Necropolítica. São Paulo: N-1 Edições.

Medeiros, E. S. (2019). Necropolítica tropical em tempos pró-Bolsonaro: Desafios contemporâneos de combate aos crimes de ódio LGBTfóbicos. Reciis, 13, 287-300. https://doi.org/10.29397/reciis.v13i2.1728

Miguez, P. (2007). Economia criativa: Uma discussão preliminar. In G. M. Nussbaumer (Ed.), Teorias e políticas da cultura: visões multidisciplinares (pp.65-113). Salvador: EDUFBA.

Pelbart, P. (2018). Necropolítica tropical: Fragmentos de um pesadelo em curso. São Paulo: N-1 Edições.

Phillips, D. (2020). Bolsonaro Fires Popular Health Minister after Dispute over Coronavirus Response. The Guardian.

https://www.theguardian.com/world/2020/apr/16/bolsonaro-brazil-president-luiz-man detta-health-minister

Ribeiro, D. (2016). A Extinção do MinC é Nefasta para o Brasil. Capitu.

https://revistacapitu.com.br/claudia-leit\%C3\%A3o-a-extin\%C3\%A7\%C3\%A3o-do-min c-\%C3\%A9-nefasta-para-o-brasil-d60a57fb37e0

Tyner, J. (2019). Dead Labor: Towards a Political Economy of Premature Death. Minneapolis, MN: University of Minnesota Press. https://doi.org/10.5749/j.ctvckq9nc 